\author{
Journal of International Business Research and Marketing \\ Volume 1, Issue 6, 2016 \\ journal homepage: www.researchleap.com
}

\title{
The Impact of Entrepreneurial Alertness on Entrepreneurial Intentions
}

\author{
Altaf Hussain Samo ${ }^{1}$, Norashidah Hashim ${ }^{2}$ \\ ${ }^{12}$ Sukkur IBA, University of Uttara Malaysia (UUM)
}

ABSTRACT

2016 Research Leap/Inovatus Services Ltd.

All rights reserved.

DOI: 10.18775/jibrm.1849-8558.2015.16.3001

URL: http://dx.doi.org/10.18775/jibrm.1849$\underline{8558.2015 .16 .3001}$

Keywords:

Entrepreneurship

Entrepreneurial Education

Entrepreneurial Alertness

Entrepreneurial Intention

\begin{abstract}
The emergence of opportunity is based on the intentions which are the result of people's belief and the way of thinking. Entrepreneurial alertness is considered vital for identifying the opportunity which can have an impact on mindset for exploiting the opportunities. The objective of this study was to analyze the connection between opportunity identification and intentions formation through entrepreneurial alertness based on the theory of planned behavior. The data was collected from the 499 final year business students of nine universities from Sindh, Pakistan using cross-sectional survey. The results of this study revealed that entrepreneurial alertness has positive and significant effect on attitude, subjective norms, perceived behavioral control and entrepreneurial intentions. The findings of this study contributed to the theory of planned behavior by taking entrepreneurial alertness as a predictor of entrepreneurial intentions. The findings also have implication for increasing the supply of entrepreneurial capital into the society.
\end{abstract}

\section{Introduction}

The process of entrepreneurship consists of capabilities to discover the opportunity, collect resource, organize them and adopt the strategy so that opportunity can be exploited (Shane, 2003). However, opportunity identification is guided by the entrepreneurial mindset which consists of alertness (Krizner, 1999). Alertness helps individual to accumulate and trigger sniffing ability which makes them capable of identifying gaps in the market that have been overlooked by others (Krizner, 1979, 1999). Moreover, alertness develops the aptitude for perceiving the change of signals in the environment for improving the decision-making quality of an individual. Shane (2000) suggested that the individual capability of identifying opportunities depends on how knowledge and information are converted and transformed. Moreover, entrepreneurial alertness is used to develop sense by accumulating, transforming and selecting information from the environment so that it can be utilized for opportunity identification (Tang, Louis \& Kacmar, 2012)). Thus the individuals need to accumulate and utilize specific and general human capital of entrepreneurial alertness for identifying and exploiting the opportunities (Solesvik, Westhead, Maltay \& Valdimir, 2013).

Literature has identified the connection of opportunity and intention formation has a potential of developing further avenues for stimulating entrepreneurial behavior (Geissler \& Zanger, 2010). According to Martin, McNally and Kay (2013) the outcome of investment in human capital i.e. knowledge and skills to identify the opportunity has a positive effect on entrepreneurial intention. Valliere (2011) argued that disparity in schematic priming might be considered to have a connection with entrepreneurial intention. Means of motivating intention can probably develop this through entrepreneurial alertness, however, this relation between entrepreneurial alertness and entrepreneurial intention need to be investigated in future research. Some studies have suggested further investigation and research to understand the relation between entrepreneurial alertness and entrepreneurial intention (Valliere, 2011).

To address this issue, this study will analyze the effect of entrepreneurial alertness on entrepreneurial intentions based on a theory of planned behavior. The organization of this paper is as following. First, we will discuss the theoretical framework and hypotheses by explaining the effect of entrepreneurial alertness on entrepreneurial intentions based on the theory of planned behavior. The next section will suggest the hypothesis of the study. The methodology section will discuss sample and method used for analyzing the data. The result section will describe findings and discuss them. Finally, the conclusion section will briefly describe the concluding remarks.

\section{Theoretical Framework}

According to Ajzen (1991), entrepreneurial intentions identify the endeavor that one make to carry out the entrepreneurial behavior. 
Ajzen (1991) in his theory of planned behavior suggested three interdependent antecedents of intentions i.e. Attitude towards behavior, Social Norms, and Perceived Behavioural Control. He further explained that as a general rule, the more favorable the three antecedents, the higher should be the individual's intention for performing the particular behavior. The model classifies personal attitude towards the behavioral outcomes, perceived social norms which reveal desirability of performing the behavior and Perceived Behavioural Control (PBC) reflects the personal competence of controlling the behavior (Ajzen, 1991). Theory of planned behavior can apply to all voluntary behavior, and it can provide an explanation in different fields, as well as the choice of becoming an entrepreneur (Ajzen, 2001; Kolvereid, 1996; Krueger et al., 2000). Several empirical studies applied and confirmed the impact of attitude, social norms, and perceived behavioral control in predicting the entrepreneurial intentions of becoming an entrepreneur (Karimi, Biemans, Thomas, Mohammad \& Martin, 2014; Koçoğlu \& Hassan, 2013; Iakovleva, Kolvereid, \& Stephan 2011).

An important aspect needed for becoming an entrepreneur is to encourage the individual by endowing them with the required skills and knowledge for identifying the opportunities and turning these opportunities into successful ventures (Shane,2000). Accordingly, Krueger (2000) the emergence of opportunity is based on the intentions which are a result of people's belief and way of thinking. Belief and desires configure the individual intentions and actions (Ajzen, 1991; Greve, 2001). The opportunity identification is guided by an entrepreneurial mindset which consists of alertness (Krizner, 1999). The role of entrepreneurial alertness for opportunity recognition has been recognized in the entrepreneurship research. However, the process of opportunity recognition and the decision for exploiting the opportunity are two different phases of the entrepreneurial process (McMullen \& Shepherd 2006). McMullen and Shepherd (2006) in their study hypothesize that alertness theory developed by Kirzner deals with attention stage during the individual decision-making process. If potential entrepreneur believes that the opportunity has profit potential, then he or she may assess their readiness to stand for the uncertainties to decide whether or not exploit the opportunity by taking entrepreneurial action. Here the process of decision making does not necessitate the actual initiation or capitalizing on the opportunity, but it is his or her intentions to do it. The study of Hou (2008) concluded that individual with strong entrepreneurial alertness more probable of identifying the opportunity which plays an important role developing individual actions to become an entrepreneur by starting a new venture. The results of this study showed that factors like environmental scanning, motivation, prior Performance, a level of education, and capability affect the entrepreneurial alertness which led to entrepreneurial action. In their study Geldern et al. (2006) showed consistent support for entrepreneurial alertness which points out that individuals' entrepreneurial alertness enhances intention and motivates them to set up their own business.

According to Langowitz and Minniti (2007), entrepreneurial alertness could guide the students to for developing a clear image of entrepreneurship and evaluate their values and motives to engage in business and their attitude toward entrepreneurship. Thus, higher the level of entrepreneurial alertness, the higher the likelihood that students may develop an attitude to pursue entrepreneurship. This reflected a direct positive and significant link between individuals reporting high alertness and an increased the likelihood to start new firms (Langowitz \& Minniti, 2007). In their study, Farsi, Arabiun \& Moradi (2012) concluded the opportunity recognition skills enhance significantly subjective norms which affect the entrepreneurial intentions. Geldern et al. (2006) study showed that entrepreneurial alertness has a significant impact on perceived behavioral control which is linked with individual entrepreneurial intention. Solesvik et al. (2013) suggested that only the students of entrepreneurship courses/programs were having a higher entrepreneurial intention when they had built up a high level of entrepreneurial alertness specific human capital.

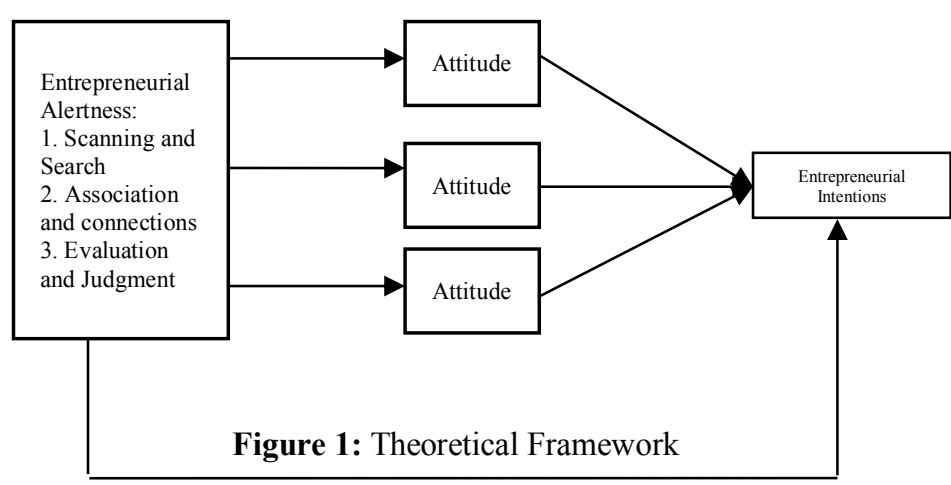

\section{Hypothesis}

H1a: Entrepreneurial alertness effects on attitude towards entrepreneurship

H1b: Entrepreneurial alertness effects on subjective norms towards entrepreneurship

H1c: Entrepreneurial alertness effects on PBC towards entrepreneurship

H2a: Attitude towards entrepreneurship effects on the students' intentions to become an entrepreneur.

$\mathrm{H} 2 \mathrm{~b}$ : Subjective norms towards entrepreneurship effect on students' entrepreneurship intentions.

H2c: Perceived behavioral control towards entrepreneurship effect on students' entrepreneurship intentions.

H3: Entrepreneurial alertness effect on Entrepreneurial Intentions.

\section{Methodology}

\subsection{Sample}

The data for the study was collected randomly through the crosssectional survey from the final year business students of nine universities of Sindh, Pakistan. The study distributed 650 questionnaires to the students and received back 523 questionnaires from the students of which 499 found usable for data analysis purpose. The effective response rate was $80 \%$, and the usable questionnaire rate was $77 \%$.

\subsection{Measurement of Variables}

This paper used the Entrepreneurial Intention Questionnaire (EIQ) by Liñán \& Chen (2009) to measure entrepreneurship 
intentions of the students. For construct of entrepreneurial alertness, this study adapted 13-item measure for developed by Tang et al. (2012). All the measures of the study used seven points Likert scale for where 1 denotes "strongly disagree" and 7 denotes "strongly agree".

\subsection{Method}

This study used structural Equation Modeling (SEM) Path analysis, using AMOS 18.0 to test the inter-relationship between dependent and independent Variables. This study applied two steps approach as suggested by (Anderson \& Gerbing, 1988).

- The assessment of the measurement model

- The evaluation of the structural model.

\section{Findings}

As a first step confirmatory factor analysis (CFA) for each variable and combined CFA based on the results of results of exploratory factor analysis was conducted. In the beginning, a measurement model of each latent constructs was stipulated where the relationships between observed variables and latent constructs were scrutinized.

The results of goodness of fit for measurement model have GFI= .79 , Ratio $=3.61, \mathrm{p}=.000, \mathrm{SRMR}=.0506, \mathrm{TLI}=.83, \mathrm{CFI}=.87$ and RMSEA $=.0706$. These indicators suggested the model is not adequate to fit. Moreover, validity analysis also suggested the validity issues in the model. The study took steps to modify the measurement model to make it a good fit. These steps include deletion of indiscriminate items, items with higher standardized residual and modification indexes.

Table 5.1: Convergent and Discriminant Validity of Construct.

\begin{tabular}{|c|c|c|c|c|c|c|c|c|c|c|c|}
\hline & CR & $\begin{array}{l}\text { AV } \\
\text { E }\end{array}$ & $\begin{array}{l}\text { MS } \\
\text { V }\end{array}$ & $\begin{array}{l}\mathbf{A S} \\
\mathbf{V}\end{array}$ & AC & Att & SN & $\begin{array}{l}\text { PB } \\
\text { C }\end{array}$ & Int & SS & EJ \\
\hline & 0.77 & 0.53 & 0.39 & 0.24 & 0.73 & & & & & & \\
\hline \multirow[t]{2}{*}{ AC } & 7 & 8 & 4 & 4 & 3 & & & & & & \\
\hline & 0.82 & 0.60 & 0.51 & 0.29 & 0.41 & 0.77 & & & & & \\
\hline \multirow[t]{2}{*}{ Att } & 2 & 7 & 6 & 7 & 0 & 9 & & & & & \\
\hline & 0.79 & 0.66 & 0.28 & 0.21 & 0.44 & 0.50 & 0.81 & & & & \\
\hline SN & 7 & 2 & 3 & 6 & 7 & 2 & 4 & & & & \\
\hline PB & 0.75 & 0.50 & 0.48 & 0.30 & 0.47 & 0.61 & 0.52 & 0.71 & & & \\
\hline \multirow[t]{2}{*}{ C } & 3 & 5 & 9 & 4 & 5 & 8 & 9 & 1 & & & \\
\hline & 0.90 & 0.75 & 0.51 & 0.31 & 0.41 & 0.71 & 0.53 & 0.69 & 0.86 & & \\
\hline \multirow[t]{2}{*}{ Int } & 1 & 3 & 6 & 2 & 3 & 8 & 2 & 9 & 8 & & \\
\hline & 0.79 & 0.66 & 0.39 & 0.25 & 0.62 & 0.53 & 0.38 & 0.46 & 0.49 & 0.81 & \\
\hline \multirow[t]{2}{*}{ SS } & 7 & 3 & 4 & 6 & 8 & 3 & 3 & 4 & 7 & 4 & \\
\hline & 0.80 & 0.66 & 0.30 & 0.21 & 0.55 & 0.42 & 0.36 & 0.48 & 0.40 & 0.49 & 0.81 \\
\hline EJ & 1 & 9 & 6 & 1 & 3 & 5 & 6 & 2 & 8 & 7 & 8 \\
\hline
\end{tabular}

According to Hooper, Coughlan and Mullen (2008) the deletion of indiscriminate items in the model likely to improve it and advantageous, if they don't have any major theoretical repercussions. The goodness of fit test of the modified model as shown in figure 4.5 was The goodness of fit test of the modified model as shown in the figure was, Ratio $=1.72, \mathrm{p}=.000$, SRMR .034 , GFI=.95 TLI.97, CFI.98, and RMSEA.038. These indicators for the test goodness of fit of indicate the model is a good fit. As a next step, it is necessary to establish convergent and discriminant validity, as well as composite reliability, when doing a CFA.

The validly analysis result as indicated in Table 5.1 all the variables have composite reliability above the cutoff level of 0.70
(Hair et al. 2010). The composite reliability as shown in the table is higher than average variance extracted and value of average variance extracted is greater than 0.5 . These results satisfy the criteria as suggested by (Hair et al. 2010) for convergent validity. The average variance extracted was much higher than average shared variance and could easily satisfy the (Farnell \& Larcker's 1981) criterion of robust evidence of discriminant validity. The maximum variance shared was also lower than the average variance extracted which is also evidence of discriminant validity (Hair et al. 2010). Once the composite reliability and construct validity measures were established, the study used all the constructs in the structural model based on hypothesized model as shown in figure 2 .

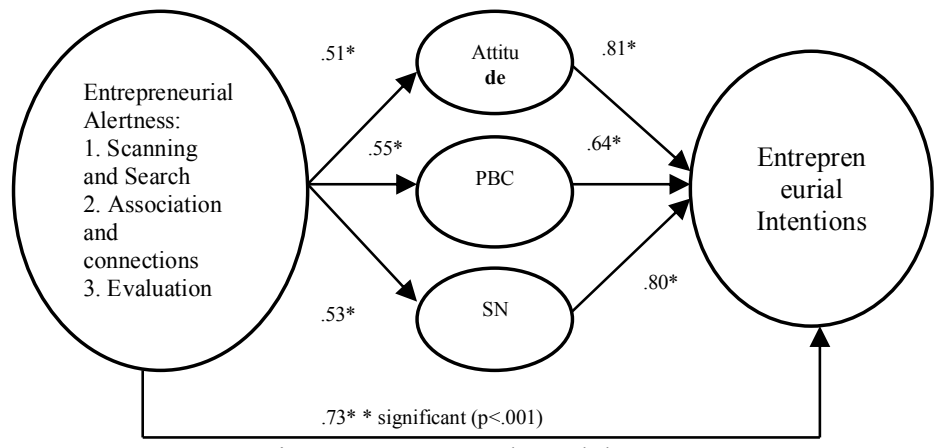

Figure 2: Structural Model

According to the finding, as shown in the table, the relationship between entrepreneurial alertness and attitude has $\beta=0.51$ and $p<.001$, entrepreneurial alertness and subjective norms has $\beta=$ 0.55 and $\mathrm{p}<.001$, entrepreneurial alertness and $\mathrm{PBC}$ has $\beta=0.53$ and $\mathrm{p}<.001$. The result of study signifies the positive and significant relationship between entrepreneurial alertness and antecedents of entrepreneurial intentions as shown in Table 5.2.

Table 5.2: Relationship between Entrepreneurial Alertness and Antecedents of Entrepreneurial Intentions

\begin{tabular}{|c|c|c|c|c|c|c|c|}
\hline & & & Estimate & S.E. & C.R. & $\mathrm{P}$ & Result \\
\hline EA & $\rightarrow$ & Attitude & .51 & .140 & 8.416 & $* * *$ & Significant \\
\hline EA & $\rightarrow$ & $\mathrm{SN}$ & .55 & .122 & 7.464 & $* * *$ & Significant \\
\hline EA & $\rightarrow$ & PBC & .53 & .094 & 8.575 & $* * *$ & Significant \\
\hline
\end{tabular}

According to the finding as shown in Table 5.3 the relationship between attitude and entrepreneurial intentions has $\beta=0.81$ and $\mathrm{p}<.001$, subjective norms and entrepreneurial intentions has $\beta=$ 0.64 and $p<.001, \mathrm{PBC}$ and entrepreneurial intentions has $\beta=0.80$ and $\mathrm{p}<.001$. The result of the study signifies the positive and significant relationship between entrepreneurial intentions and antecedents of entrepreneurial intentions as shown in Table 5.2 
Table 5.3: Relationship between EI and antecedents of entrepreneurial intentions

\begin{tabular}{llllllll}
\hline & & & Estimate & S.E. & C.R. & P & Result \\
\hline Attitude & $\rightarrow$ & EI & .81 & .059 & 13.502 & $* * *$ & Significant \\
$\mathrm{SN}$ & $\rightarrow$ & EI & .64 & .062 & 10.635 & $* * *$ & Significant \\
$\mathrm{PBC}$ & $\rightarrow$ & EI & .80 & 053 & 12.010 & $* * *$ & Significant \\
\hline
\end{tabular}

The relationship between entrepreneurial alertness and intentions had $\beta=0.73$ and $p<.001$ as shown in Table 5.4.

Table5.4: Relationship between Entrepreneurial Alertness and Entrepreneurial Intentions

\begin{tabular}{lllllll}
\hline & & Estimate & S.E. & C.R. & P & Result \\
\hline EA $\rightarrow$ & EI & .73 & .156 & 8.928 & $* * *$ & Significant \\
\hline
\end{tabular}

\section{Discussion}

The major objective of this study was to analyze the impact of entrepreneurial alertness on entrepreneurial intentions based on the theory of planned behavior. Moreover, this study has also examined the relationship between entrepreneurial alertness and the three antecedents of entrepreneurial intentions. The result of this study as shown in Table 5.2 indicated that attitude, subjective norms, and $\mathrm{PBC}$ have a positive and significant effect on entrepreneurial intentions hence hypothesis one ( $a, b$ and $c)$ is accepted. These results are consistent with the result of previous studies of Karimi et al., (2014); Krueger \& Carsrud, (1993); Iakovleva, Kolvereid, \& Stephan (2011). This is the reconfirmation of the theory of planned behavior in predicting the entrepreneurial intentions from developing countries context in general and Pakistani context in particular.

The results of 2 nd hypothesis for this study as shown in Table 5.3 suggested that entrepreneurial alertness has a positive effect on the attitude, subjective norms and PBC. Hence the hypothesis 2 ( $\mathrm{a}, \mathrm{b}$ and $\mathrm{c}$ ) is also accepted. The findings for hypothesis 2 (a,b and c) are consistent with the findings of Langowitz \& Minniti, (2007); Farsi et al., (2012); Geldern et al., (2008). These findings suggested that entrepreneurial alertness could be useful in developing a clear image of entrepreneurship among the students. Moreover, entrepreneurial alertness guides them in evaluating their values and motives to engage in entrepreneurial activities, and their attitude toward entrepreneurship (Langowitz \& Minniti, 2007). Thus, a higher level of entrepreneurial alertness results in a higher likelihood that students develop an attitude for pursuing entrepreneurship. Entrepreneurial alertness also increases confidence in them that entrepreneurship is achievable as they can identify the opportunity (Linan \& Chen, 2009). This resulted in enhancing their PBC. A higher level of entrepreneurial alertness also helps in increasing the sense of understanding values and motives of entrepreneurship those lead the students to interact with the significant entrepreneurial experts (Practicing entrepreneurs, teachers and guest speakers) effectively which significantly affect the subjective norms (Farsi et al., 2012).
The findings of this study as shown in Table 5.3 suggest that entrepreneurial alertness has a positive and significant effect on entrepreneurial intentions of the students. Hence, 3rd hypothesis accepted. These findings are consistent with the findings of Hou (2008); Geldern et al., (2008); Martin et al., (2013); Solesvik et al. (2013). These findings reiterate that if an individual is alert, then he may develop the intentions for exploiting the opportunities. As described by McMullen \& Shepherd (2006), the process of opportunity recognition and the decision for exploiting the opportunity are considered two different aspects of the entrepreneurial process. However, when an alert individual identifies the opportunity with profit potential, he may decide to exploit that opportunity based on his knowledge and motivation.

The finding of this study indicated entrepreneurial alertness have a positive impact and sign cant impact on intention creation, which is considered to be useful to enhance our understanding of the new business creation process from the very beginning. Moreover, entrepreneurial alertness could play a vital role in developing entrepreneurial intentions of potential entrepreneurs. Based upon the dynamic view of human capital theory, human capital is set of idiosyncratic skills and competencies like entrepreneurial alertness. Solesvik et al., (2013) concluded that students who accumulated the higher level of entrepreneurial alertness reported the higher level of entrepreneurial intentions. In other words, the specific human capital like entrepreneurial alertness is a key element for enhancing the entrepreneurial capital from a human capital theory perspective.

This study may be one of few studies, which has identified the relationship between entrepreneurial alertness and entrepreneurial intentions based on the theory of planned behavior. Moreover, this study is also unique from developing countries context in general and Pakistan in particular. This study also contributed to the theory of planned behavior by empirically proving entrepreneurial alertness as an important element for predicting the entrepreneurial intentions. Moreover, this study also signified that for improving the supply of entrepreneurial capital in the society enhancing entrepreneurial alertness is a vital element. Thus, improving entrepreneurial alertness ability of individual through different means such as entrepreneurial education could be used.

\section{Conclusions}

The process of entrepreneurship consists of capabilities to discover the opportunity, collect resource, organize them and adopt the strategy so that opportunity can be exploited. The opportunity identification process is guided by entrepreneurial mindset, which consists of alertness. The findings of this study reiterate that if the individual is alert, then he may develop the intentions for exploiting the opportunities because entrepreneurial alertness affects the attention stage during individual decisionmaking process by having an impact on attitude, subjective norms, and PBC. This resulted in the development of belief and desires which configure the individual intentions and actions that can lead to perceiving new feasible venture. Therefore, entrepreneurial alertness may be considered as an important 
element for increasing the supply of entrepreneurial capital in the society.

\section{References}

- Ajzen, I. (1991). The theory of planned behavior. Organizational behaviour and human decision processes, 50(2), 179-211, CrossRef

- Ajzen, I. (2001). Nature and operation of attitudes. Annual review of psychology,52(1), 27-58, CrossRef

- Ajzen, I. (2002). Perceived Behavioural Control, Self - Efficacy, Locus of Control, and the Theory of Planned Behaviour1. Journal of applied social psychology,32(4), 665-683, CrossRef

- Anderson, J. C. and D. W. Gerbing (1988) "Structural Equation Modeling in Practice: A Review and Recommended Two-Step Approach," Psychological Bulletin (103)3, Fall, pp. 411-423, CrossRef

- Baron, R., \& Ensley, M. (2006). Opportunity recognition as the detection of meaningful patterns: Evidence from comparisons of novice and experienced entrepreneurs. Management Science, 52(9), 1331-1344, CrossRef

- Chin, A. (1998). The morphologic structure of step-pools in mountain streams. Geomorphology, 27(3), 191-204.

- Davidson, P., \& Honing, B. (2003). The Role of Social and Human Capital Among Nascent Entrepreneurs. Journal of Business Venturing, 20, 121, CrossRef

- Davidson, P., \& Honing, B. (2003). The Role of Social and Human Capital Among Nascent Entrepreneurs. Journal of Business Venturing, 20, 121, CrossRef

- Douglas, E. J., \& Shepherd, D. A. (2002). Self-employment as a career choice: attitudes, entrepreneurial intentions, and utility maximization. Entrepreneurship Theory and Practice, 26(3), 81-90.

- Elfving, J., Brännback, M., \& Carsrud, A. (2009). Toward a contextual model of entrepreneurial intentions. Understanding the entrepreneurial mind (pp. 23-33). Springer New York, CrossRef

- European Commission. (2006). Entrepreneurship education in Europe: Fostering entrepreneurial mindsets through education and learning. In Final proceedings of the conference on entrepreneurship education in Oslo.

- Farsi, J. Y., Arabiun, A., \& Moradi, M. (2012). The Impact of Opportunity Recognition Skills Training on Entrepreneurial Intention of Female Nursing Students. Journal of Knowledge Management, Economics \& Information Technology, 2(4).

- Fayolle, A., Gailly, B., \& Lassas-Clerc, N. (2006). Assessing the impact of entrepreneurship education programmes: a new methodology. Journal of European Industrial Training, 30(9), 701720, CrossRef

- Gaglio, C. M., \& Katz, J. A. (2001). The psychological basis of opportunity identification: Entrepreneurial alertness. Small Business Economics, 16(2), 95-111, CrossRef

- Geissler, M, \& Zanger,C. (2010). Factors on the perception of entrepreneurial opportunities and their influence on entrepreneurialintention - an empirical study. International Council of Small Buisness Conference Hooper, D., Coughlan, J., \& Mullen, M.R. (2008). Structural equation modelling: Guidelines for determining model fit. Journal of Business Research Methods, 6, 5360.

- Gelderen. V, M., Brand, M., van Praag, M., Bodewes, W., Poutsma, E., \& Van Gils, A. (2008). Explaining entrepreneurial intentions by means of the theory of planned behaviour. Career Development International, 13(6), 538-559, CrossRef

- Hair, J. F., Black, B., Babin, B., Anderson, R. E., and Tatham, R. L. (2010). Multivariate Data Analysis: A Global Perspective. New Jersey, USA: Pearson Education Inc, CrossRef

- Hattab, H. W. (2014). Impact of Entrepreneurship Education on Entrepreneurial Intentions of University Students in Egypt. Journal of Entrepreneurship, 23(1), 1-18, CrossRef

- Hou, S. T. (2008). Antecedents and consequence of entrepreneurial alertness in franchise chain. In Management of Innovation and Technology, 2008. ICMIT 2008. 4th IEEE International Conference on (pp. 166-171).
- Iakovleva, T., Kolvereid, L., \& Stephan, U. (2011). Entrepreneurial intentions in developing and developed countries. Education+ Training, 53(5), 353-370, $\underline{\text { CrossRef }}$

- Karimi, S., Biemans, H. J., Lans, T., Chizari, M., \& Mulder, M. (2014). The Impact of entrepreneurship education: A study of Iranian students' entrepreneurial intentions and opportunity identification. Journal of Small Business Management.

- Kirzner, I. M. (1979). Perception, opportunity, and profit: Studies in the theory of entrepreneurship). Chicago: University of Chicago Press.

- Kirzner, I. M. (1985) . The Perils of Regulation: A Market Process Approach,in Discovery and the capitalist process. Chicago: University of Chicago Press, 1985

- Kirzner, I. M. (1997). Entrepreneurial discovery and the competitive market process: An Austrian approach. Journal of economic Literature, 35(1), 60-85.

- Kirzner, I. M. (2009). The alert and creative entrepreneur: a clarification. Small Business

- Kocoglu, M., \& Hassan, M. U. (2013). Assessing Entrepreneurial Intentions of University Students: A Comparative Study of Two Different Cultures: Turkey and Pakistani. European Journal of Business and Management, 5(13), 243-252.

- Kolvereid, L. (1996). Organizational employment versus selfemployment: reasons for career choice intentions. Entrepreneurship Theory and Practice, 20(3), 23-32.

- Krueger, N. F., \& Carsrud, A. L. (1993). Entrepreneurial intentions: applying the theory of planned behaviour. Entrepreneurship \& Regional Development, 5(4), 315-330, CrossRef.

- Krueger, N. F., Reilly, M. D., \& Carsrud, A. L. (2000). Entrepreneurial intentions: A competing models approach. Journal of Business Venturing,15(5/6), 411-432, CrossRef

- $\quad$ Langowitz, N., \& Minniti, M. (2007). The entrepreneurial propensity of women.Entrepreneurship theory and practice, 31(3), 341-364, CrossRef

- Li-án, F., \& Chen, Y. W. (2009). Development and Cross - Cultural application of a specific instrument to measure entrepreneurial intentions. Entrepreneurship Theory and Practice, 33(3), 593-617, CrossRef

- Martin, B. C., McNally, J. J., \& Kay, M. J. (2013). Examining the formation of human capital in entrepreneurship: A meta-analysis of entrepreneurship education outcomes. Journal of Business Venturing, 28(2), 211-224, CrossRef

- McMullen, J. S., \& Shepherd, D. A. (2006). Entrepreneurial action and the role of uncertainty in the theory of the entrepreneur. Academy of Management Review, 31(1), 132-152, CrossRef

- McStay, D. (2008). An investigation of undergaduate student selfemployment intention and the impact of entrepreneurship education and previous entrepreneurial experience. Theses

- Menzies, T. V., \& Paradi, J. C. (2003). Entrepreneurship education and engineering students-Career path and business performance. The International Journal of Entrepreneurship and Innovation, 4(2), 121 132, CrossRef

- Shane, S. A. (2003). A general theory of entrepreneurship: The individual-opportunity nexus. Edward Elgar Pub, CrossRef

- Shane, S., \& Venkataraman, S. (2000). The promise of entrepreneurship as a field of research. Academy of management review, 25(1), 217-226, CrossRef, CrossRef

- Saks, N. T., \& Gaglio, C. M. (2002). Can opportunity identification be taught?. Journal of Enterprising Culture, 10(04), 313-347, CrossRef

- Solesvik Marina, Westhead Paul, Matlay Harry , N. Parsyak Vladimir , (2013) "Entrepreneurial assets and mindsets: Benefit from university entrepreneurship education investment", Education + Training, Vol. 55 Iss: 8/9, pp.748 - 762

- Tang, J., Kacmar, K. M. (Micki), \& Busenitz, L. (2012). Entrepreneurial alertness in the pursuit of new opportunities. Journal of Business Venturing, 27(1), 77-94, CrossRef

- Valliere, D. (2011). Towards a schematic theory of entrepreneurial alertness. Journal of Business Venturing, 28(3), 430-442, CrossRef 